\title{
Organizational Management Technologies for Maintenance and Repair of Power Grid Company Facilities
}

\author{
Larisa Ismagilova \\ Ufa State Aviation Technical University \\ USATU \\ Ufa, Russian Federation \\ ismagilova_ugatu@mail.ru
}

\author{
Larisa Sitnikova \\ Ufa State Aviation Technical University \\ USATU \\ Ufa, Russian Federation \\ s_larissa@yandex.ru
}

\begin{abstract}
The article deals with the issue of organizational management of equipment maintenance and repair in a power grid company. A new concept of management has been formulated which reconciles the controversial requirements of cost efficiency and reliability. The peculiar feature of the proposed concept is that, firstly, the condition of company's electrical engineering and infrastructural facilities is monitored; secondly, and the equipment performance analysis is carried out taking into account probable breakdowns; thirdly, economic losses from equipment failures are evaluated; fourthly, power consumers become categorized; fifthly, repair works become rated by their urgency. The proposed concept has the integrating idea of shaping a balance of production features, risks and maintenance and repair costs. Due to introduction of the maintenance and repair management based on the newly formulated concept, the repair schedules become optimized in terms of cutting down the likeliness of failures and retaining the company's economic efficiency. Some ingenious tools are offered for implementing the organizational management technology: a graphical chart of multi-dimensional positioning of facilities in the "customer categorization - facility technical condition" coordinates; a method of calculating the economic losses; a consumer category matrix; a summary table of repair urgency rating. The herein proposed matching concept of organizational management is noted for adaptability and multi-aspect analysis of the factors reflecting the interests of grid companies and power consumers. The expediency and practicality of the proposed organizational management technology are confirmed with calculations of an optimal maintenance and repair scheme as exemplified on a regional power grid company.
\end{abstract}

Keywords - tecnology and tools of organizational management; power grid company; risk assessment; production equipment repair and maintenance schedule.

\section{INTRODUCTION}

The trends of production management development in the innovation economy are focused on developing technological adaptability of organizational management in a present-day company. An important place in the industrial management is given to the functional part of organizational management of production equipment maintenance and repair.

Power grid companies, being subjects of market relations, follow the principle of economic efficiency in their activities. On the other hand, due to specific nature of the sector, they have to meet the requirement of providing energy security to their consumers.

Development of a maintenance and repair (M\&R) management system for power grid company's facilities is based on two well-tested approaches [1]. The first one implies the reliability assessment and management in compliance with underlying regulatory requirements on maintenance and repair timing [2, 3]. This approach includes a well-developed methodological apparatus allowing one to plan scheduled preventive repairs (SPR) using standardization and indices rating. The other approach to equipment maintenance and repair management is based on monitoring the equipment condition and assessing the risks [4-8]. In that case, the reliability management focuses mainly on estimating probable failures of equipment, both that of the power grid company itself and the one operated by consumers. However, the actual data from incident monitoring do not meet the criteria of statistical homogeneity and repeatability. This circumstance makes the application of reliability forecasting methods problematic and does not ensure a long-term SPR mapping.

In the new conditions for operating power grid companies and restructuring the sector in general, the organizational management technologies come into conflict with the companies' strategic purposes which imply economic results. The proposed reconciling concept of organizational management is characterized by the process adaptability, multi-aspect analysis of the factors describing the interests of grid companies and power consumers and is aimed at minimizing aggregate economic losses incurred in operating the power grid.

The technology of M\&R organizational management in a power grid company is based on this article-contemplated concept, which brings together the economic interests, power security requirements and consumer categorization. The SPR schedules may be built within this technology based on the facility repair urgency rating as the tool providing data on equipment condition, consumer category and economic loss estimation related to equipment failure risk. The proposed approach will allow a set of tools for substantiating production management decisions in order to assess risks and expediency 
while scheduling repairs, without lowering the grid company reliability and power safety requirements.

\section{DRAWBACKS IN M\&R MANAGEMENT PRACTICES}

Traditionally, to maintain technical condition while operating the equipment, the grid companies use the production management SPR schemes based on the regulatory technical documentation requirements. In the new economic environment and due to reorganization of the electric power complex, the situation has changed dramatically, and the system drawbacks became evident:

- firstly, repair works are scheduled and held regardless of the equipment's actual condition, which results in excessive stocks of tools, spare parts and materials;

- secondly, managing the M\&R system is carried out without taking into account the significance of losses and the after-shutdown recovery costs to consumer;

- thirdly, in scheduling the M\&R, a number of constraints (technological, material, labor) is neither taken into account, nor provided the optimization of schedules from the standpoint of rational managing the equipment operation.

Overspending the resources within the regulation-guided technical maintenance and repair does not fit with the economic and financial stability and investment appeal of grid power companies, resulting in excessive padding of the budget.

The organizational management of a company business in a competitive environment brings to the fore the economic criteria of managing the company and its assets while unconditionally ensuring the reliable power supply to consumers [9-12]. The economic, financial and investment efficiency targets become determinative in the development strategies of power grid companies. In current circumstances, operating a company brings specific requirements to production management, since it is effected within uncertain external and partially internal environment. These requirements are linked to a set of market, economic, financial, process and other risks.

The risks in a company's business derive from specific features of the sector: the synchronism of production and consumption, the government regulation and natural monopoly status in the power transmission and distribution. It should be noted that in the formerly existing conditions of centralized planning and management in the power industry any consideration of risks was not relevant. Then risks were linked to possible technological malfunctions or equipment failures, while the economic and financial conditions for the companies operation were stabilized with the state regulation methods.

\section{M\&R ORGANIZATIONAL MANAGEMENT TECHNOLOGY WITHIN RECONCILIATION CONCEPT}

The proposed concept of power grid company organizational management has the integrating idea of setting a balance of equipment production features, risks and repair costs. The proposed approach is based on assessing the significance of electric and infrastructural facilities in terms of production parameters, assessing the consequences for consumers, accounting the economic losses and repair costs [13].

In the proposed system of organizational management of production equipment maintenance and repair in a power grid company, certain blocks are formed that determine repair schedules based on the main principles of the reconciling concept:

- firstly, the principle of monitoring and recording the technical condition of equipment and determining the risk of failure occurrence;

- secondly, the principle of accounting the economic losses from equipment failures;

- thirdly, the principle of categorizing the consumers by the maintenance and recovery urgency.

The M\&R control system is intended to improve the scheduling of maintenance and repair of equipment in terms of reducing the likeliness of possible failures and maintaining its functionality through its condition monitoring and assessing. The proposed concept is to be implemented in the organizational management system as the technique of substantiating management decisions as presented by the combination of methods, calculation diagrams, analysis tools.

The organizational management technology includes:

- methods of economic losses evaluation;

- a consumer category matrix;

- graph-analytical tools of multi-dimensional positioning and a summary table of repair urgency rating.

\section{A. Methods of Assessing Economic Losses}

Methods of economic losses evaluation represent a system of estimated cost indices which determine non-recoverable losses, repair and restoration costs, costs due to the decrease in production possibilities (loss of profit), damage from deterioration of process parameters, reimbursement of damages to consumers, indemnification of environmental damage, compensation for social damage.

The calculation of likely occurrence of breakdowns and failures, depending on the equipment condition and operation, is an important element of economic loss assessment method. The risk analysis cannot be performed based only on the information included in the aggregated register of production assets. Additional indicators are required; their values cannot always be found in the company documents or equipment specifications. Some of them have to be determined through calculation, resulting from the analysis of failure statistics or expert surveys. The function of failure rate $\lambda(t)$ in the power transmission and distribution sector may be represented in a linearized form [14]:

$$
\lambda(t)=a_{0}+b \times\left(t-t_{c r}\right), \quad t>t_{c r}
$$


where $t$ - lifetime; $t_{c r}$ - boundary of the specified operation range; $a_{0}$ - value of the failure rate function in the normal operation range; $b$ - the function growth ratio in the wear range.

The failure occurrence probability is assessed using the statistical and expert data. In this case, the $\lambda(t)$ function appearance may vary depending on the causes of failures, such as random nature, cyclic loads, fatigue, etc. [15].
To calculate the risk rate in an economic equivalent, a multiplicative model may be used, realized in the form of methods (Table I):

$$
R_{i}=\lambda(t) \times U_{i}
$$

where $R_{i}$ - materialized (economic) risks of the $i$-equipment failures; $\lambda(t)$ - likeliness of failures; $U_{i}$-damages incurred by company. The value of damage does not always coincide with the costs of equipment repair or replacement.

TABLE I. Methods Of ECONOMIC Losses Evaluation

\begin{tabular}{|c|c|c|}
\hline Type of costs & Computation scheme & Note \\
\hline $\begin{array}{l}\text { Non-recoverable } \\
\text { losses }\end{array}$ & $\begin{array}{l}\qquad U_{1}=\sum S_{r i}+\sum S_{m j}+S_{o t h} \\
\text { where } S_{r i}-\text { residual book value of the irrecoverable } i- \\
\text { equipment; } S_{m j}-\text { cost of the j-materials; } S_{o t h}-\text { other } \\
\text { expenses on fault elimination, rescue works, etc. }\end{array}$ & $\begin{array}{l}\text { Identified through investigation of a process breach by estimating the } \\
\text { cost of irrecoverable losses of equipment (liquid value of the } \\
\text { damaged equipment and structures), materials, fuel. }\end{array}$ \\
\hline $\begin{array}{l}\text { Repair and } \\
\text { restoration costs }\end{array}$ & $\begin{array}{l}\qquad U_{2}=S_{\text {rep }}+S_{a d j} \\
\text { where } S_{\text {rep }} \text { and } S_{a d j} \text { are the estimated costs of repair and } \\
\text { adjustment works. }\end{array}$ & Identified based on estimated costs of repair and adjustment works. \\
\hline $\begin{array}{l}\text { Costs due to the } \\
\text { decrease in } \\
\text { production } \\
\text { possibilities (loss of } \\
\text { profit) }\end{array}$ & $\begin{array}{l}\qquad U_{3}=\sum W_{u s i}\left(T_{i}\right) \times P_{i} \\
\text { where } P_{i}-\text { average price of } 1 \mathrm{kWh} \text { of electric energy for the } \\
i \text {-consumer with regard to tariffs; } W_{u s i}\left(T_{i}\right) \text { - undersupply of } \\
\text { power during the limitation period or shutdowns due to } \\
\text { technical problems }\left(T_{i}\right) \text {. }\end{array}$ & $\begin{array}{l}\text { Loss of profit is calculated which is caused by reduced supply of } \\
\text { power to consumers due to failures. A profit loss is to be determined } \\
\text { in case a process breach results in an essential change of net power } \\
\text { flows and a shutdown or restriction of power supply to consumers. } \\
\text { The undersupplied power shall be determined as the difference } \\
\text { between average daily consumption for the nearest similar period } \\
\text { with normal power supply (a working day, a day-off), preceding the } \\
\text { restriction or shutdown and the actual consumption during the period } \\
\text { of power undersupply to consumer. }\end{array}$ \\
\hline $\begin{array}{l}\text { Damage from } \\
\text { deterioration of } \\
\text { process parameters }\end{array}$ & $\begin{array}{l}\qquad U_{4}=P_{a v} \times W_{l s}\left(T_{i}\right) \\
\text { where } P_{a v} \text { is the average price of } 1 \mathrm{kWh} ; W_{l s}\left(T_{i}\right) \text { is the loss } \\
\text { of electric energy for the period of changed operation of the } \\
\text { power grid }\left(T_{i}\right) \text {. }\end{array}$ & $\begin{array}{l}\text { The damage from deterioration of process parameters is to be } \\
\text { determined in case of process violations in the power system if they } \\
\text { do not result in essential changes in the power grid operating mode. } \\
\text { The damage arises in case of increased specific costs on the } \\
\text { substituting equipment, increased load losses in the grid, deviation in } \\
\text { the post-emergency operation from the normal mode. }\end{array}$ \\
\hline $\begin{array}{l}\text { Reimbursement of } \\
\text { damages to } \\
\text { consumers }\end{array}$ & $\begin{array}{l}\qquad U_{5}=\sum S_{c m l} \\
\text { where } S_{c m l} \text { is the amount payable to the } l \text {-consumer of the } \\
\text { electric energy. }\end{array}$ & $\begin{array}{l}\text { Arises from power supply cuts or restrictions and is determined as per } \\
\text { commercial agreements with consumers of electric energy. }\end{array}$ \\
\hline $\begin{array}{l}\text { Indemnification of } \\
\text { environmental and } \\
\text { social damage }\end{array}$ & $\begin{array}{l}\qquad U_{6}=S_{p n}+S_{e n} \\
\text { where } S_{p n} \text { is the amount of penalty for environmental } \\
\text { consequences and payments pursuant to the laws on social } \\
\text { security and protection of population; } S_{e n} \text { is the costs of } \\
\text { works to eliminate environmental consequences. }\end{array}$ & $\begin{array}{l}\text { Includes the payments and (or) the cost of works on eliminating the } \\
\text { environmental consequences of process violations. The social } \\
\text { consequences of a process violation are characterized with the } \\
\text { number of people wounded, diseased and deceased. }\end{array}$ \\
\hline
\end{tabular}

The materialized (economic) risk parameter is the mathematical expectation of economic damage a power grid company will suffer in case of an equipment breakdown of certain type. This parameter evaluates the materialized risk for each facility asset of the company and for voltage class independently [16].

The evaluation of economic losses is the first stage in organizational management of maintenance and repair. 


\section{B. Consumer Category Matrix}

The peculiarity of maintenance and repair management in a power grid company is in the need to assess consumer significance in terms of energy security.

In order to determine the consumer category score, each consumer who is technologically connected to a facility is referred to a class in accordance with the matrix of consumer categorization (Table II). Each of the factors in consumer categorization matrix is assigned scores, and then the total rate of scoring is determined for the facility categorization. As an example, a calculation of $6 \mathrm{kV}$ class facility score is reviewed. The consumer is technologically connected to a facility with the following parameters: expected damage - RUR 570 thous. (6 points), power supply category - II (6 points), consumption - $320.000 \mathrm{kWh}$ (10 points), emergency and technological reservation (15 points +9 points), sector - mechanical engineering (10.5 points). The facility's resulting amount of 56.5 points determines the place in the category rating of maintenance.

TABLE II. CONSUMER CATEGORY MATRIX (AN EXCERPT)

\begin{tabular}{|c|c|c|c|c|c|}
\hline \multirow{3}{*}{ Factors } & \multirow{3}{*}{ Criteria } & \multicolumn{4}{|c|}{ Voltage class, $\mathrm{kV}$} \\
\hline & & 0.4 & $6(10)$ & $1 \quad 35$ & 110 \\
\hline & & \multicolumn{4}{|c|}{ points } \\
\hline \multirow{5}{*}{$\begin{array}{l}\text { Physical risk level } \\
\text { (expected damage) }\end{array}$} & over RUR50mln & & & & 50.0 \\
\hline & RUR10mnl to RUR50mln & & & 20.0 & 30.0 \\
\hline & RUR1mnl to RUR10mln & & 9.0 & 13.0 & 20.0 \\
\hline & RUR0.1mnl to RUR1mln & 4.0 & 6.0 & 9.0 & 13.0 \\
\hline & under RUR0.10mnl & 2.0 & 3.0 & 4.5 & 7.0 \\
\hline \multirow[t]{4}{*}{$\begin{array}{l}\text { Power receiver } \\
\text { category }\end{array}$} & $\begin{array}{l}\text { Special category (a continuous operation is necessary for an accident-free } \\
\text { stoppage of production to avoid life hazards, explosions and fires) }\end{array}$ & 10.0 & 15.0 & 22.0 & 40.0 \\
\hline & $\begin{array}{l}\text { Category I (a power-cut may cause life and safety hazards, heavy physical } \\
\text { damage, violation of a sophisticated technological process, malfunction of vital } \\
\text { utilities, communication facilities or TV) }\end{array}$ & 7.0 & 10.0 & 15.0 & 25.0 \\
\hline & $\begin{array}{l}\text { Category II (a power-cut results in massive under-production, large-scale } \\
\text { downtime of workforce, mechanisms and industrial transport, disruption of usual } \\
\text { activities for significant number of urban and rural residents) }\end{array}$ & 4.0 & 6.0 & 9.0 & 13.0 \\
\hline & Category III (all the rest) & 1.0 & 1.5 & 3.0 & 5.0 \\
\hline \multirow{4}{*}{$\begin{array}{l}\text { Monthly consumption, } \\
\text { thous. kWh }\end{array}$} & under 10.8 & 1.0 & 1.5 & & \\
\hline & from 10.8 to 108 & 4.0 & 6.0 & 9.0 & \\
\hline & from 108 to 482.4 & 7.0 & 10.0 & 15.0 & 25.0 \\
\hline & over 482.4 & & 15.0 & 22.0 & 40.0 \\
\hline \multirow{3}{*}{$\begin{array}{l}\text { Reservation } \\
\text { availability }\end{array}$} & Emergency reservation & 10.0 & 15.0 & 22.0 & 40.0 \\
\hline & Technological reservation & 5.0 & 9.0 & 13.0 & 20.0 \\
\hline & No ETR & 0.0 & 0.0 & 0.0 & 0.0 \\
\hline \multirow{6}{*}{$\begin{array}{l}\text { Consumer group (an } \\
\text { excerpt) }\end{array}$} & Continuous production plants in any sectors & & & 22.5 & 33.8 \\
\hline & Steel mills & & & 22.5 & 33.8 \\
\hline & Crude oil producers & & 12.0 & 18.0 & 27.0 \\
\hline & Machine engineering plants & & 10.5 & 15.8 & 23.6 \\
\hline & Agricultural consumers & 2.0 & 3.0 & & \\
\hline & Population: 1 point per 100 customers & 1.0 & 1.5 & & \\
\hline \multicolumn{2}{|c|}{ Total for each consumer (sum of maximum values) } & 108.5 & & & 203.75 \\
\hline
\end{tabular}

In case it is necessary to assess the category of a group of consumers, the scoring is effected through successive totalling of points by facilities "upwards" - opposite to the supply direction (Fig. 1).

\section{Power Supply Center}

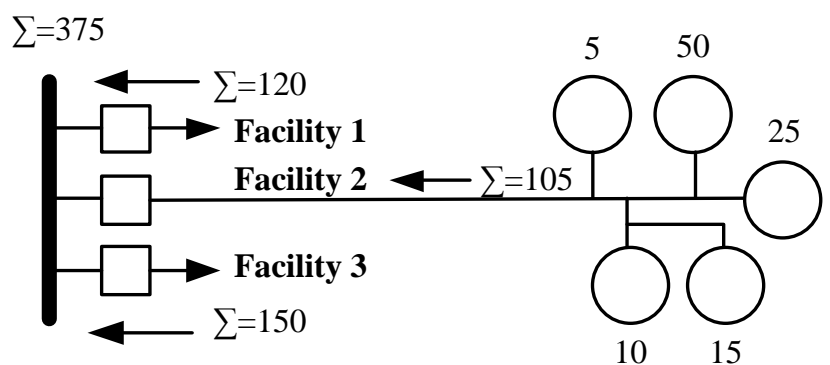

Fig. 1. An example of calculating the total scoring of a consumer group
The proposed calculation scheme has been tested for the main types of power grid equipment at Iskino substation - a major power company in the region.

\section{Graph-Analytical Tools of Multi-Dimensional Positioning And a Summary Table of Repair Urgency Rating}

To estimate the likely occurrence of a risk, the organizational management technology has graphic-analytical set of tools combining:

- the materialized risk computation scheme, based on the economic loss evaluation methods;

- the consumer category matrix;

- graphical tools of multi-dimensional positioning.

The proposed set of tools allows the implementation of main ideas of the stated reconciliation concept. The structure of the tool set corresponds to main blocks in the M\&R management system and allows the dynamic scheduling of equipment maintenance and repair which improves economic 
performance while retaining the reliability and energy security requirements.

The multi-dimensional positioning graphical tools (Fig. 2) help in substantiating the decisions on setting the priorities and adjusting the repair schedules. The figure shows the change of equipment position in the "technical condition - consumer category" coordinates relative the risk area boundary (the «DELTA» value). The obtained coordinate values characterize the likeliness of risk occurrence in case of equipment breakdown or category change when connecting a new consumer. These data are used in the $M \& R$ system to make the repair urgency rating.

In the process of operation, the technical condition of a facility deteriorates, which is reflected in the change of the facility's position on the coordinate plane - the position moves along the 'technical condition' axis downward (from position S1 to position S1') with the constant consumer category point value (Fig. 2). After prevention or repair works, the facility's position moves upwards along the 'technical condition' axis.

Upon technological connection of a new consumer and the grid topology change, the facility categorization and scoring are updated. In that case, the facility position on the coordinate plane moves along the $\mathrm{y}$-axis (from position $\mathrm{S} 2$ to position S2') with the constant value of the facility's technical condition.

Resulting from the multi-dimensional positioning (Fig. 2), a summary repair urgency table is made, in which the facility is rated for repair cost and risk emergence (Table III).

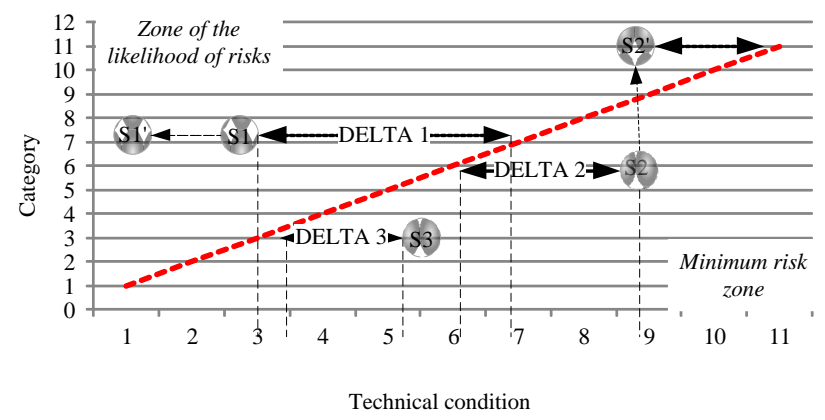

Fig. 2. Graphic tools of multi-dimensional positioning

TABLE III. SUMMARY TABLE OF REPAIR URGENCY RATING

\begin{tabular}{|l|l|l|l|}
\hline Facility & $\begin{array}{c}\text { Repair cost, } \\
\text { RUR thous. }\end{array}$ & $\begin{array}{c}\text { Risk } \\
\text { occurrence } \\
\text { rate (DELTA) }\end{array}$ & \multicolumn{1}{c|}{ Note } \\
\hline S1 & 100 & 3.8 & $\begin{array}{l}\text { High risk, the 1stposition } \\
\text { in priority rating }\end{array}$ \\
\hline S 2 & 50 & -2.3 & $\begin{array}{l}\text { Low risk, low position in } \\
\text { the priority rating }\end{array}$ \\
\hline S 3 & 75 & -1.8 & $\begin{array}{l}\text { Higher risk, position in the } \\
\text { priority rating is higher } \\
\text { than the previous }\end{array}$ \\
\hline
\end{tabular}

The summary of the table containing repair urgency rating makes the basis for decisions on $M \& R$ scheduling in respect of facilities of a power grid company. The practical value of the proposed organizational management technology is in that it allows substantiating $M \& R$ decisions with a sufficient degree of objectivity.

The importance of decisions on making the repair priority rating with regard to situation analysis is confirmed with the concept of performance reliability assessment of a power grid company. The principles of situational management based on technical condition of plant assets and on matching the technical condition with consumer category scoring allow the M\&R scheduling with regard to company's economic strategies and development objectives while retaining the requirements to reliability and safety of power grid operation.

\section{EXAMPLE OF IMPLEMENTING THE TECHNOLOGY OF EQIPMENT MAINTENANCE AND REPAIR ORGANIZATIONAL MANAGEMENT AT ISKINO SUBSTATION}

Introduction of the proposed approach at a power grid company plant confirms the expediency of overall estimation of equipment condition when scheduling maintenance and repair within the matching concept of organizational management.

After calculating the consumer categorization and taking into account the received information on the facility technical condition at Iskino substation, 9 facilities $(10 \mathrm{kV}$ grid equipment) were positioned in multidimensional coordinates (Fig. 3). The positioning involves parameters of real facilities with numbers in the substation equipment register.

To assess the situation for risk occurrence, the equipment condition value was introduced on the chart for each facility, which enables specifying the facility position in the repair urgency rating. Location of facilities in the positioning field relative to risk zone boundary determines the repair urgency rating.

The positioning results show that facilities No. 20 and No. 12 being in an unsatisfactory technical condition are not critical in terms of inflicting a considerable damage. On the contrary, facility No. 6 being in a good technical condition yet falls into the area of a likely risk occurrence. Thus, the M\&R schedule needs to be adjusted with regard to the repair urgency rating of the analysed facilities.

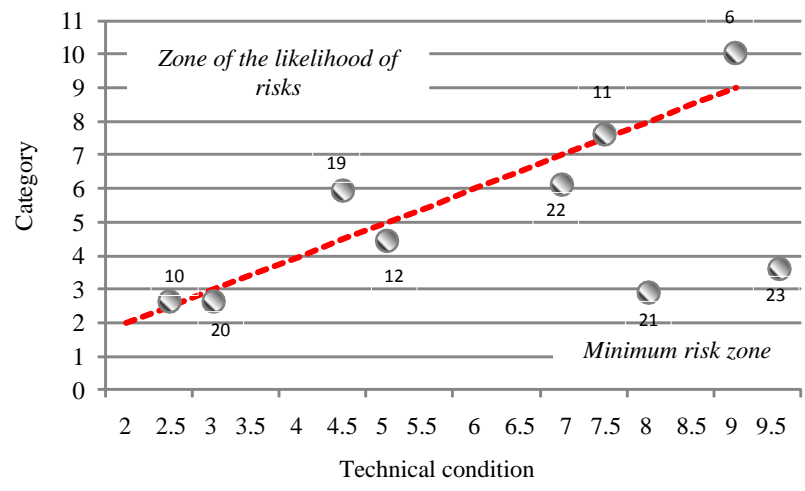

Fig. 3. Positioning of facilities at Iskino substation

An excerpt of calculation data by facilities: equipment type «10 kV switch», equipment model «VMPE-10-20/630» at 
Iskino substation is presented in Table IV. The example of rating the equipment repair urgency for Iskino power grid company, as shown in the table, confirms practical value of the organizational management technology built according to the proposed matching concept. The M\&R scheduling under the proposed technique reduced the repair costs by $4.3 \%$ without impairing general reliability.

TABLE IV. RATING THE REPAIR URGENCY IN M\&R ORGANIZATIONAL MANAGEMENT TECHNOLOGY

\begin{tabular}{|c|c|c|c|c|c|c|}
\hline \multirow[b]{2}{*}{ 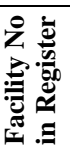 } & \multirow[b]{2}{*}{$\begin{array}{l}\text { Equipment } \\
\text { condition (IC } \\
\text { estimation) }\end{array}$} & \multirow[b]{2}{*}{$\begin{array}{l}\text { Physical risk } \\
\text { (exposure) as at the } \\
\text { current time, } \\
\text { RUR/year }\end{array}$} & \multirow[b]{2}{*}{$\begin{array}{l}\text { Equipment } \\
\text { technical } \\
\text { condition in } \\
\text { points }\end{array}$} & \multicolumn{2}{|c|}{ Category } & \multirow[b]{2}{*}{$\begin{array}{c}\text { Repair urgency } \\
\text { rating }\end{array}$} \\
\hline & & & & $\begin{array}{l}\text { Calculated amount of } \\
\text { points per facility }\end{array}$ & $\begin{array}{c}\text { Rated amount of } \\
\text { points to show on } \\
\text { the coordinates } \\
\text { plane }\end{array}$ & \\
\hline 6 & Good & 120000.00 & 9 & 70 & 10.0 & 2 \\
\hline 10 & Unfit & 150000.00 & 2.5 & 18.5 & 2.6 & 3 \\
\hline 11 & Good & 200000.00 & 7.5 & 53 & 7.6 & 4 \\
\hline 12 & Satisfactory & 110000.00 & 5 & 31 & 4.4 & 6 \\
\hline 19 & Satisfactory & 120000.00 & 4.5 & 41.5 & 5.9 & 1 \\
\hline 20 & Unfit & 120000.00 & 3 & 18.5 & 2.6 & 5 \\
\hline 21 & Good & 90000.00 & 8 & 20.5 & 2.9 & 8 \\
\hline 22 & Good & 140000.00 & 7 & 43 & 6.1 & 7 \\
\hline 23 & Good & 100000.00 & 9.5 & 25.5 & 3.6 & 9 \\
\hline
\end{tabular}

\section{CONCLUSION}

The matching concept proposed herein is notable for multi-aspect analysis of the factors that describe interests of power grid company and power consumers. The designed organizational management technology differs in that the management conciliates the company business interests, power safety requirements and power grid reliability. The organizational management technology makes a basis for the equipment $M \& R$ system which minimizes aggregate economic losses in the grid operation.

The organizational management system for power grid company equipment (and other productive assets) maintenance and repair is based on the block structure of graph-analytical tools which are designed to substantiate decisions on assigning the repair urgency ratings and adjusting the M\&R schedules. The decisions made conciliate economic priorities, the reliability characteristics and the degree of responsibility to consumers depending on their category.

The practical calculations performed by the example of making the repair urgency rating for facilities of Iskino substation - a unit of a major power grid company in the region - confirm practicality of the technology and graphanalytical tools of the organizational management of equipment technical maintenance and repair. The proposed concept-based scheduling of M\&R in a power grid company allows improving the economic efficiency, without reducing the grid operation reliability, while providing energy security for the economy and population.

\section{References}

[1] I. O. Volkova.,M. A. Muravyov and V. P. Gorshenin, "Development of Managerial Decisions in Management of Productive Assets of a Power Grid Company", Bulletin of the South Ural State University. Ser. Economics and Management, vol. 10(4), pp. 76-87, December 2016.

[2] I. E. Buyanov, "Approaches to maintenance engineering", Industrial power engineering, vol. 1, pp. 7-10, January 2015.
[3] M. Ershov and I. Skrelev, "Models for planning repairs and replacing industrial electrical equipment", Industrial power engineering, vol. 11, pp. 29-34, November 2005.

[4] A. V. Serebryakov, O. V. Kryukov and V. G. Titov, "Forecasting the Technical Condition of Wind Power Plants", Electrical engineering, vol. 1, pp. 60-65, January 2017.

[5] A. V. Serebryakov and O. V. Kryukov, "System of Operational Diagnostics of the Technical Condition of Wind Power Plants", Electrical engineering, vol. 4, pp. 49-53, April 2015.

[6] V. S. Genin, V. V. Koznov, S. O. Feldman, "Diagnostic Monitoring in Distribution Networks", Electrical engineering, vol. 2, pp. 35-40, February 2015.

[7] S. P. Vysotsky, "Technical Risks and Fault Insurance in the Operation of Energy Equipment", Industrial power engineering, vol. 6, pp. 19-23, June 2016.

[8] A. Yu. Khrennikov, O. V. Grinko and P. S. Radin, "Evaluation of the Electrical Equipment Technical Condition in "FGC UES" Substitutions with the Use of Software and Information Instruments", Industrial power engineering, vol. 3, pp. 12-17, March 2015.

[9] A. V. Agunov, T. S. Titova abd V. A. Krucek, "About the Construction of Electricity Quality Management Systems", Electrical engineering, vol. 5, pp. 14-19, May 2016.

[10] A. V. Valyansky, I. I. Kartashev and Yu. V. Sharov, "Estimation of Electrical Supply Reliability with Electricity Quality", Electrical engineering, vol. 5, pp. 16-21, May 2014.

[11] V. Valyansky, I. I. Kartashev and Yu.V. Sharov, "Influence of Electricity Quality on the Reliability of a Power Transformer", Electrical engineering, vol. 3, pp. 20-27, March 2014.

[12] B. I. Kudrin, "Electric Power Today and Issues of Consumer Electric Supply", Industrial power engineering, vol. 10, pp. 5-9, October 2016.

[13] L.A. Ismagilova and N.A. Suhova, "Assessment of quality of innovative technologies", International Journal for Quality Research, vol. 10(4), pp. 707-718, December 2016.

[14] V. I. Kolibaba and A.A. Filatov, “ Development of methods for managing physical assets of a power grid company based on probabilistic simulation", Bulletin of ISEU, vol. 2, pp. 61-65, April 2016.

[15] A. A. Filatov, "Evaluation of physical risks grid companies using Markovski simulation", Bulletin of ISEU, vol. 1, pp.26-29, February 2007.

[16] K. V. Varlashkin and I. O. Volkova, "Methodical aspects of an estimation of a management efficiency of grid companies", Economics, vol. 10, pp.172-177, October 2007. 